\title{
Laporan Kasus: Perawatan Splinting Wire pada Pasien Periodontitis disertai Diabetes Melitus
}

\author{
(Case Report: Splinting Wire Treatment in Periodontitis Patients with Diabetes Mellitus)
}

Inneke Cahyani ${ }^{1}$, Ghina Giovani Putri ${ }^{2}$

' Bagian IImu Penyakit Mulut, Kedokteran Gigi, Universitas Jenderal Soedirman, Purwokerto, Jawa Tengah

2 Kedokteran Gigi, Universitas Jenderal Soedirman, Purwokerto, Jawa Tengah

\section{Abstrak}

Periodontitis menyebabkan kerusakan perlekatan gigi ke tulang dan dapat menjadi predisposisi penyakit sistemik. Diabetes mellitus merupakan faktor risiko penyakit periodontal, kedua penyakit ini berkorelasi; Penyakit periodontal dapat disebabkan oleh infeksi bakteri yang disebabkan oleh perubahan sistem kekebalan karena diabetes mellitus serta peradangan kronis yang disebabkan oleh penyakit periodontal menyebabkan kontrol glikemik yang buruk pada pasien ini. Laporan kasus: Seorang wanita 56 tahun mengeluh mobilitas pada gigi anterior. Pemeriksaan intra oral ditemukan kebersihan mulut cenderung buruk, luksasi grade 211 , kehilangan perlekatan klinis $6,5 \mathrm{~mm}$, resesi gingiva $3,5 \mathrm{~mm}$, dan kedalaman probing $3 \mathrm{~mm}$. Dia telah didiagnosis diabetes mellitus dan 2 tahun yang lalu dan memiliki perawatan medis untuk penyakit ini. Terapi yang diberikan berupa edukasi, scaling, dan splinting wire. Diskusi: Diabetes mellitus berhubungan dengan kerusakan ligamen periodontal yang selanjutnya dapat menyebabkan kehilangan gigi. Cairan sulkus gingiva dan saliva memiliki konsentrasi mediator inflamasi yang lebih tinggi termasuk berbagai jenis sitokin di antara pasien diabetes dengan periodontitis dibandingkan dengan individu non-diabetes dengan penyakit periodontal. Kesimpulan: Periodontitis kronis pada penderita diabetes melitus harus dipantau secara berkala baik kadar glukosa darah maupun kontrol plak di rongga mulut.

Kata kunci: diabetes mellitus, kawat belat, periodontitis kronis,

\begin{abstract}
Periodontitis causes destruction of tooth attachment to bone and may predispose to systemic disease. Diabetes mellitus is a risk factor for periodontal disease, these two diseases are correlated; periodontal disease can be favored by bacterial infection caused by an alteration of the immune system because of diabetes mellitus as well as chronic inflammation caused by periodontal disease leads to poor glycemic control in these patients. Case report: A 56 years old female complaining of mobility at anterior teeth. Intra oral examination was found oral hygiene tends to be poor, 11 th grade 2 luxation, 6,5 mm clinical loss attachment, 3,5 mm gingival recession, and $3 \mathrm{~mm}$ probing depth. She had been diagnosed diabetes mellitus and 2 years ago and has medical treatment for this diseases. The therapy provided is in the form of education, scaling, and splinting wire. Discussion: Diabetes mellitus is associated with periodontal ligament destruction which subsequently can lead to tooth loss. Gingival crevicular fluids and saliva have higher concentrations of inflammatory mediators including different types of cytokines among diabetic patients with periodontitis as compared to non-diabetic individuals with periodontal disease. Conclusion: Chronic periodontitis in patients with diabetes melitus must be monitored periodically both blood glucose levels and plaque control in the oral cavity.
\end{abstract}

Keywords: Chronic periodontitis, diabetes mellitus, splinting wire.

Korespondensi (Correspondence) : Ghina Giovani Putri. Kedokteran Gigi, Universitas Jenderal Soedirman, Purwokerto. Jl. Dr. Soeparno, Kampus Karangwangkal Gedung E, Karang Bawang, Grendeng, Kec. Purwokerto Utara, Kabupaten Banyumas, Jawa Tengah 53122. Email: ghinagiovaniputri.gg@gmail.com

Periodontitis adalah penyakit inflamasi pada jaringan pendukung gigi yang disebabkan oleh mikroorganisme spesifik.' Bakteri yang sering dijumpai pada penderita periodontitis antara lain bakteri spesifik gram negatif seperti Porphyromonas gingivalis, Provotella intermedia, dan Aggregatibacter actinomycetemcomitans. ${ }^{2}$ Beberapa faktor risiko apabila saling berinteraksi terutama dengan penyebabnya utama dapat meningkatkan keparahan periodontitis meliputi faktor lokal seperti plak, kalkulus, faktor iatrogenik (restorasi yang overhanging, terbukanya kontak proksimal pada restorasi), penggunaan tembakau, dan maloklusi serta faktor sistemik seperti kekurangan nutrisi, kelainan endokrin, kelainan hematologi, penyakit imunodefisiensi, dan keturunan. ${ }^{1}$

Klasifikasi dari periodontitis yang digunakan menurut American Academy of Periodontology (AAP) pada saat ini antara lain periodontitis kronis, periodontitis agresif, dan periodontitis yang disebabkan oleh penyakit sistemik.' Periodontitis kronis merupakan jenis periodontitis yang paling umum dengan prevalensi lebih banyak ditemukan pada usia diatas 35 tahun. Penyakit ini berkaitan erat dengan akumulasi plak dan kalkulus. Pemeriksaan klinis akan terdapat peningkatan kedalaman probing, perdarahan saat probing, kemerahan dan pembengkakan pada gingiva. Pemeriksaan radiografi menunjukkan bahwa kerusakan tulang umumnya memiliki pola horizontal, meskipun memungkinkan terjadi dengan pola vertikal. ${ }^{2}$

Salah satu penyakit sistemik yang berhubungan dengan periodontitis yaitu diabetes melitus. Diabetes melitus merupakan penyakit gangguan metabolik berupa hiperglikemia diakibatkan defisiensi dan kegagalan pankreas dalam memproduksi insulin di dalam tubuh sehingga akan terganggunya meta-bolisme karbohidrat, protein, dan lemak. ${ }^{3,4}$ Diabetes melitus ditandai 
dengan kondisi hiperglikemia, yaitu kurangnya aktivitas hormon insulin dalam proses metabolisme glukosa. Kondisi normal glukosa puasa (preprandial) $70-120 \mathrm{mg} / \mathrm{dL}$ dan kadar glukosa sewaktu (postprandial) <140 mg/L. ${ }^{5}$ Diabetes melitus memiliki manifestasi didalam rongga mulut atau disebut oral diabetik berupa infeksi jamur berupa kandidiasis, burning mouth syndrome, gingivitis, periodontitis, neurosensoris, gangguan rasa, dan meningkatnya resiko karies. ${ }^{6}$

Komplikasi biasanya terjadi akibat hiperglikemia dapat menurunkan daya tahan tubuh penderita akibat penurunan fungsi selsel Polymorfonuclear (PMN), dan xerostomia akibat poliuri. Periodontitis memiliki keterikatan yang kuat dengan diabetes melitus, karena keadaan keduanya saling mempengaruhi. Keadaan periodontitis tidak bisa ditanggulangi dan semakin parah maka resiko kehilangan gigi akan semakin besar.7 Tujuan dari artikel ini adalah untuk menggambarkan penyakit periodontitis yang dihubungkan dengan diabetes mellitus sehingga didapatkan rencana perawatan yang sesuai.

\section{LAPORAN KASUS}

Seorang wanita berusia 56 tahun datang ke RSGM Universitas Jenderal Soedirman dengan keluhan gigi depan atas goyang dan ingin dilakukan perawatan pada gigi goyang tersebut. Pasien merasa tidak nyaman dengan gigi yang goyang apabila dipakai untuk mengunyah. Pasien mengakui memiliki penyakit diabetes melitus sejak tahun 2017 dan mengikuti PROLANIS di Puskesmas setempat serta rutin mengkonsumsi obat metformin 500 mg 2 kali sehari yaitu pagi sebelum sarapan dan malam hari. Pasien pernah ke dokter gigi untuk dilakukan pemeriksaan rongga mulut. Tidak ada riwayat keluarga yang menderita diabetes melitus. Pasien seorang ibu rumah tangga.

Pemeriksaan umum menunjukkan pasien datang dalam keadaan compos mentis, berat badan $65 \mathrm{~kg}$, tinggi badan $160 \mathrm{~cm}$, tekanan darah $120 / 80 \mathrm{mmHg}$, nadi $76 x /$ menit, pernapasan $16 x /$ menit, dan suhu $36,5^{\circ} \mathrm{C}$. Pemeriksaan ekstraoral menunjukkan wajah simetris dengan warna kulit sawo matang, limfonodi tidak teraba, dan TMJ dalam keadaan normal. Pemeriksaan intraoral menunjukkan adanya debris dan kalkulus supragingiva hampir semua regio dengan $\mathrm{OHI}-$ $S=3,75$ (buruk). Resesi gingiva pada gigi 15, 14, $13,12,21,23,24,25,35,34,33,43,44,46$ sebesar $3 \mathrm{~mm}$, gigi 11 sebesar $3,5 \mathrm{~mm}$, gigi 16 dan 26 bagian palatal sebesar $5,5 \mathrm{~mm}$. Probing depth rata-rata $3 \mathrm{~mm}$. Clinical attachment lost (CAL) pada gigi 36 dan 37 sebesar $5,5 \mathrm{~mm}$ sedangkan pada gigi 11,16 , dan 26 sebesar $6,5 \mathrm{~mm}$. Kehilangan gigi 17, 12, 22, 36, 32, 31, 41,42 , dan 45. Mobilitas gigi dengan derajat kegoyangan 2 ditemukan pada gigi 1 1, 16, 34, 43 , 44, sedangkan pada gigi 21, 33 mobilitas gigi dengan derajat kegoyangan 1. Terdapat sisa akar gigi pada posterior rahang bawah (gambar 1-5).

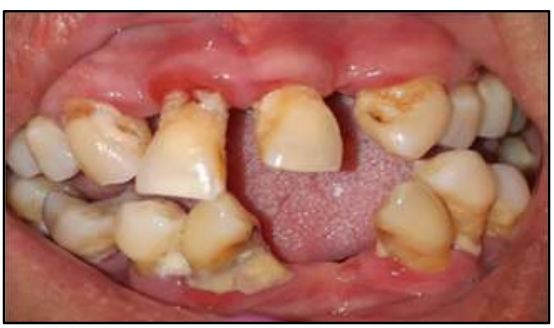

Gambar 1. Gambaran klinis pasien menunjukan resesi gingiva pada gigi 11 dan 21 , serta adanya kehilangan gigi $31,32,41,42$.

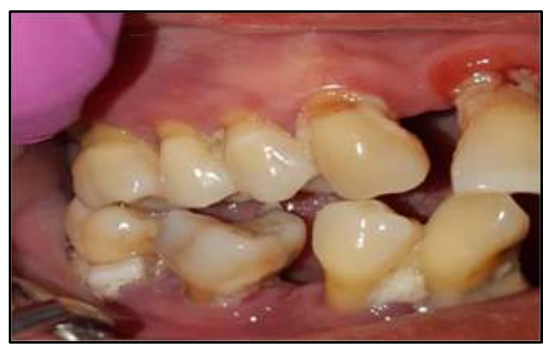

Gambar 2. Gambaran klinis pasien menunjukan resesi gingiva pada gigi posterior dextra serta akumulasi kalkulus

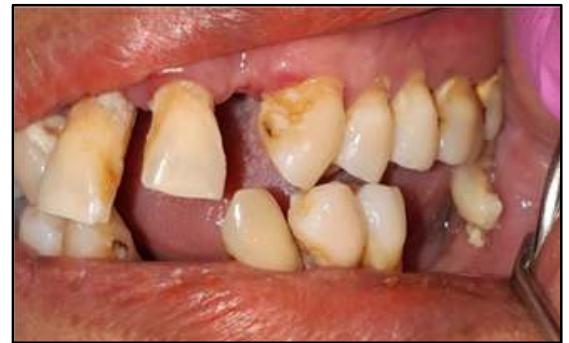

Gambar 3. Gambaran klinis pasien menunjukan adanya kalkulus, pada gigi posterior sinistra.

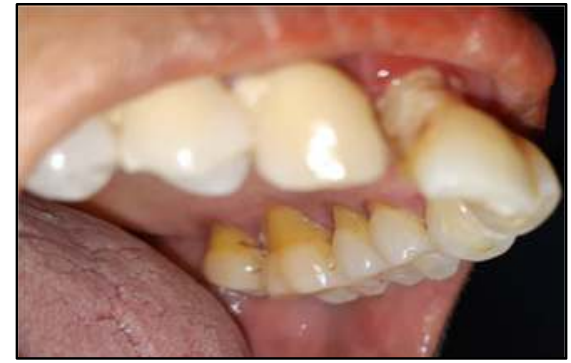

Gambar 4. Gambaran klinis pasien menunjukan resesi gingiva pada gigi 27,26 , 25 , dan 24

Pasien dijelaskan mengenai diagnosis, rencana perawatan, komplikasi, efek samping, serta hasil perawatan dan pasien telah menyetujui. Pasien selanjutnya dilakukan pemeriksaan penunjang berupa rontgen panoramik. Berdasarkan hasil rontgen ditemukan adanya resorpsi tulang alveolar secara horizontal pada anterior rahang atas 
dan posterior rahang atas serta rahang bawah.

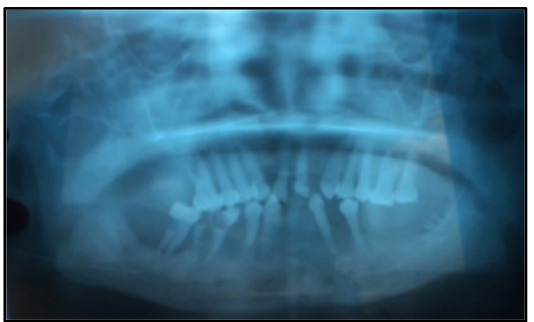

Gambar 5. Gambaran radiografi panoramik.

Pasien selanjutnya dirujuk internal ke Laboratorium Klinik untuk dilakukan pemeriksaan gula darah sewaktu. Hasil pemeriksaan gula darah sewaktu adalah 214 $\mathrm{mg} / \mathrm{dl}$. Pemeriksaan gula darah menunjukkan hasil yang lebih tinggi daripada nilai gula darah sewaktu normal yaitu $<140 \mathrm{mg} / \mathrm{dl}$. Pasien dinyatakan menderita penyakit diabetes melitus.

Diagnosis pada kasus ini yaitu periodontitis kronis generalisata disebabkan karena kalkulus diperparah oleh penyakit sistemik diabetes melitus. Kondisi yang mendukung diagnosis ini adalah terdapat kalkulus supragingiva dan subgingiva, resesi gingiva, pembengkakan gingiva, margin gingiva yang berwarna kemerahan dan kegoyangan gigi. Rencana perawatan yang dilakukan meliputi komunikasi, instruksi, dan edukasi (KIE), meng-komunikasikan rencana perawatan berupa scaling supragingiva pada semua regio, menginstruksikan penggunaan obat kumur 3 kali sehari, edukasi cara mengosok gigi yang baik dan benar, rutin dalam mengkonsumsi obat diabetes, dan menginstruksikan untuk kontrol 1 minggu yang akan dating (gambar 6-8).

Pada pertemuan 1 minggu berikutnya dilakukan pemeriksaan gula darah sewaktu dengan hasil 199,3 mm/dL. Pemeriksaan intraoral dengan hasil $\mathrm{OHI}-\mathrm{S}=1,75$ (sedang), sudah tidak terdapat kalkulus supragingiva pada semua regio, tetapi masih terdapat pembengkakan pada margin gingiva anterior rahang atas dan kegoyangan gigi. Perawatan selanjunya dilakukan yaitu splinting pada gigi depan atas yang mengalami kegoyangan (gambar 9-10).

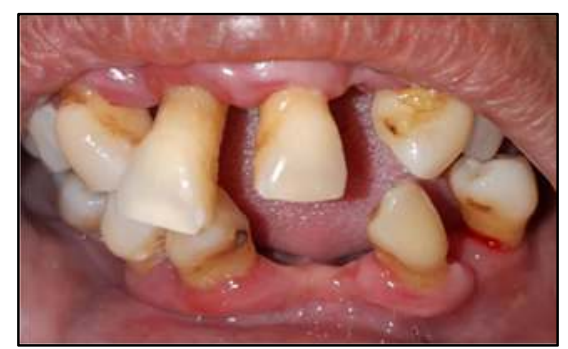

Gambar 6. Kondisi gigi anterior setelah dilakukan scaling masih terdapat resesi gingiva pada gigi 11 dan 21 .

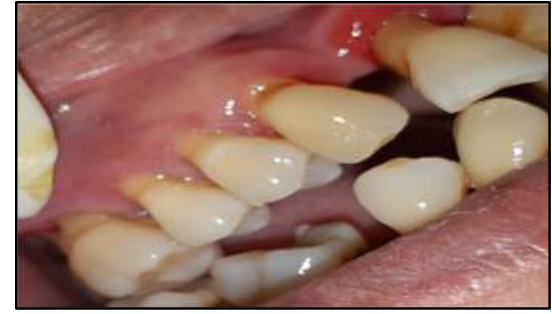

Gambar 7. Kondisi gigi posterior dextra setelah dilakukan scaling

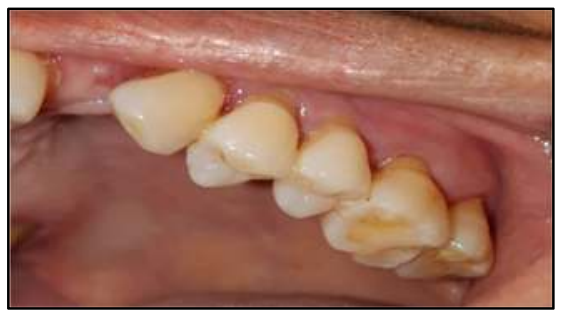

Gambar 8. Kondisi gigi posterior sinistra maksila setelah dilakukan scaling

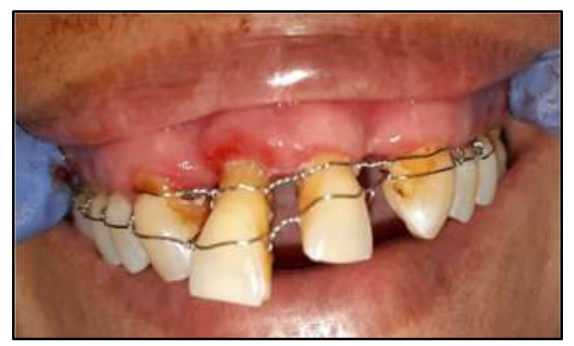

Gambar 9. Kondisi rongga mulut pasien

setelah dilakukan splinting dengan wire.

Pada pertemuan berikutnya dilakukan splinting dengan wire ligature teknik essig pada gigi $15,14,13,11,21,23,24$, dan 25 . Metode ini menggunakan wire primer dengan diameter $0,3 \mathrm{~mm}$ dan wire sekunder dengan diameter $0,28 \mathrm{~mm}$. Edukasi kepada pasien tidak untuk menggigit makanan keras. Instruksi untuk kontrol setelah 1 minggu dan 1 bulan pasca perawatan.

Pada pertemuan 1 bulan berikutnya dilakukan pemeriksaan intraoral dengan hasil $\mathrm{OHI}-\mathrm{S}=1,25$ (sedang), tidak terdapat kalkulus supragingiva pada semua regio, tetapi masih terdapat pembengkakan pada margin gingiva anterior rahang atas, resesi gingiva gigi $11=3,5 \mathrm{~mm}, 21=3 \mathrm{~mm}$ dan kegoyangan gigi sudah berkurang.

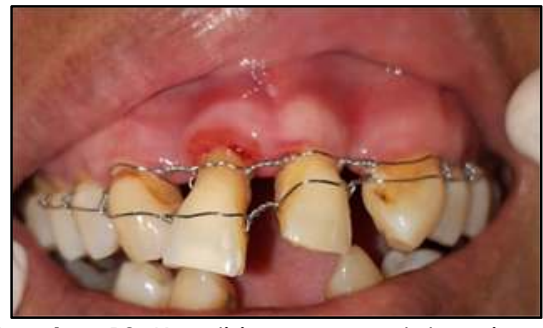

Gambar 10. Kondisi rongga mulut pasien setelah dilakukan splinting satu bulan. 


\section{PEMBAHASAN}

Periodontitis adalah penyakit inflamasi pada jaringan pendukung gigi yang disebabkan oleh bakteri spesifik.' Bakteri yang sering dijumpai pada penderita periodontitis antara lain bakteri spesifik gram negatif seperti Porphyromonas gingivalis, Prevotella intermedia, dan Aggregatibacter actinomycetemcomitans. Ada beberapa faktor risiko baik lokal maupun sistemik yang dapat meningkatkan keparahan periodontitis. ${ }^{2}$

Faktor lokal yang dapat memperparah penyakit periodontitis antara lain plak, kalkulus, faktor iatrogenik (restorasi yang overhanging, terbukanya kontak proksimal pada restorasi), penggunaan tembakau, dan maloklusi. Faktor sistemik yang dapat berpengaruh terhadap jaringan periodontal antara lain kelainan endokrin, kelainan hematologi, penyakit imunodefisiensi, dan genetik.?

Klasifikasi dari periodontitis yang digunakan menurut American Academy of Periodontology (AAP) yaitu periodontitis kronis, periodontitis agresif, dan periodontitis disebabkan penyakit sistemik.' Periodontitis kronis merupakan inflamasi kelanjutan dari gingiva yang sudah sampai mengenai dari jaringan periodontal yang memiliki perkembangan penyakit secara lambat dengan pola kerusakan tulang secara horizontal. Penyakit ini biasanya terjadi pada usia diatas 35 tahun. Tingkat keparahan dari periodontitis sebanding dengan jumlah akumulasi plak dan kalkulus dalam rongga mulut. Periodontitis kronis dapat dibedakan lagi menjadi dua jenis antara lain periodontitis kronis lokalisata dan generalisata. ${ }^{2}$

Periodontitis kronis lokalisata dapat dilihat dari keterlibatan gigi apabila mengenai kurang dari $30 \%$ area dalam rongga mulut. Periodontitis kronis generalisata dapat dilihat dari keterlibatan gigi apabila mengenai lebih dari $30 \%$ area dalam rongga mulut. ${ }^{1}$

Periodontitis agresif merupakan inflamasi pada jaringan periodontal yang memiliki perkembangan penyakit secara cepat dan pola kerusakan tulang secara vertikal. Tingkat keparahan periodontitis agresif tidak terpengaruh oleh jumlah akumulasi plak dan kalkulus. ${ }^{1}$

Periodontitis disebabkan karena penyakit sistemik yang berkaitan antara lain kelainan hematologi seperti leukemia dan neutropenia, kelainan genetik seperti sindrom down, sindrom cohen, sindrom pavillon leferve, dan sindrom ehler danlos, penyakit diabetes mellitus tipe 1, serta AIDS yang memiliki manifestasi oral periodontitis. Dampak dari kelainan sistemik tersebut antara lain mempengaruhi mekanisme pertahanan dari hospes seperti defisiensi perlekatan leukosit, dan neutropenia. ${ }^{2}$

Salah satu penyakit sistemik yang berhubungan dengan periodontitis yaitu diabetes melitus. Diabetes melitus adalah suatu kondisi tingginya glukosa dalam darah akibat defisiensi insulin, resistensi jaringan terhadap insulin atau keduanya yang dapat mengarah pada komplikasi. Diabetes melitus dibedakan menjadi 2, yaitu diabetes tipe 1 dan 2.4

Diabetes melitus tipe 1 atau disebut juga diabetes melitus tergantung insulin yang disebabkan karena kurangnya sekresi insulin akibat sel $\beta$ pankreas tidak atau sangat sedikit menghasilkan insulin. Diabetes melitus tipe 1 merupakan proses autoimun yang melibatkan destruksi selektif sel $\beta$ pankreas oleh limfosit T. Diabetes melitus tipe 1 membutuhkan insulin eksogen untuk dapat bertahan hidup. ${ }^{5}$

Diabetes melitus tipe 2 atau disebut juga diabetes melitus tidak tergantung insulin yang disebabkan karena penurunan sensitivitas jaringan target terhadap efek metabolik insulin, disebut juga dengan resistensi insulin. Diabetes melitus tipe 2 sekresi insulin mungkin normal atau bahkan meningkat, tetapi sel sasaran insulin kurang peka terhadap insulin. 4,5

Kasus pada pasien diatas merupakan diabetes melitus tipe 2 yang merupakan jenis diabetes yang banyak ditemukan pada usia diatas 45 tahun keatas dikarenakan penurunan fungsi sel $\beta$ pankreas sebagai penghasil insulin. 5 Penyakit diabetes melitus memiliki beberapa komplikasi yang terlihat pada kesehatan rongga mulut, seperti terjadinya gingivitis dan periodontitis, kehilangan perlekatan gingiva, hilangnya jaringan periodontal, kegoyangan gigi geligi, dan kehilangan dini dari gigi geligi, perdarahan spontan dari jaringan, xerostomia, burning tongue, sakit saat diperkusi dan lain sebagainya yang berhubungan dengan kelainan jaringan periodontal. ${ }^{6}$ Kegoyangan gigi pada pasien dengan diabetes melitus disebabkan oleh hilangnya perlekatan yang berhubungan dengan kurangnya kontrol glikemik. ${ }^{5}$

Penderita diabetes melitus tidak terkontrol memiliki kadar glukosa dalam saliva dan cairan krevikular gingiva (GCF) lebih tinggi dibandingkan dengan penderita diabetes melitus yang terkontrol. 5 Peningkatan kadar glukosa juga berkakibat pada kandungan lapisan biofilm dan plak pada permukaan gigi yang berfungsi sebagai tempat perlekatan bakteri sehingga me-nyebabkan terjadinya karies dan perkembangan penyakit periodontal. Pada penderita diabetes melitus akan terjadi perubahan vaskularisasi serta gangguan metabolisme mineral sehingga lebih mudah terjadi periodontitis yang selanjutnya merupakan faktor etiologi resorpsi tulang secara patologis. ${ }^{6}$

Penyembuhan luka merupakan salah satu masalah pada penderita diabetes melitus, terutama pada penderita diabetes tidak terkontrol. Penyembuhan luka yang lambat disebabkan oleh tingginya kadar gula dalam darah yang mempengaruhi fungsi fagositosis, seperti neutrofil. ${ }^{5}$ Fungsi fagositosis dan kemotaksis neutrofil akan berkurang termasuk memakan dan membunuh bakteri intraselular ketika terpapar kadar glukosa 
dalam darah yang berubah. Kelainan pembuluh darah kecil biasanya terdapat pada pasien dengan diabetes melitus sehingga mengganggu distribusi nutrisi, oksigen dan sel-sel inflamasi pada sisi perlukaan. ${ }^{7}$ Kondisi hiperglikemi jangka panjang akan mengarah ke pembentukan glikasi yaitu glukosa mengikat protein dan molekul lain melalui proses non enzimatik. ${ }^{8}$ Hasil dari glikasi menyebabkan disfungsi neutrofil, mengganggu perfusi pembuluh darah, kerusakan saraf perifer yang progresif, semua hal ini memiliki keterlibatan sistemik dan berkontribusi pada penyembuhan luka yang lambat. $^{5}$

Pasien dengan diabetes melitus yang membutuhkan tindakan bedah minor maupun mayor harus memperhatikan hal-hal seperti resiko peningkatan infeksi terutama pada pasien dengan diabetes tidak terkontrol, lambatnya penyembuhan luka, dan kemungkinan terjadinya ketoasidosis. Terapi antibiotik diberikan sebelum dan setelah ekstraksi gigi untuk mencegah kemungkinan infeksi. Tindakan bedah pada pasien dengan diabetes melitus harus dilakukan ketika kadar gula darah berada di bawah kadar kontrol. ${ }^{9}$

Prosedur dental seperti pem-bedahan atau pencabutan gigi pada pasien diabetes melitus perlu adanya kerjasama antara dokter gigi dan dokter spesialis penyakit dalam karena harus memperhatikan pencegahan infeksi dan penyembuhan luka yang terhambat. ${ }^{2}$ Beberapa hal yang harus diperhatikan sebelum prosedur invasi adalah kadar glukosa darah preprandial sebesar 70$120 \mathrm{mg} / \mathrm{dl}$ dan postprandial <180mg/dL. ${ }^{5}$ Pemberian terapi profilaksis sebelum dilakukan perawatan juga dianjurkan untuk meminimalisasi adanya infeksi. Anestesi dengan vaso-konstriktor perlu diperhatikan karena dapat meningkatkan kadar glukosa darah. 9

Perawatan periodontal bertujuan untuk menghilangkan faktor penyebab penyakit periodontal, mengembalikan fungsi dari gigi, mengurangi serta mencegah penularan atau penjalaran keparahan penyakit.1.9 Perawatan periodontal dapat dilakukan dalam beberapa fase.

Fase I (intial terapi) atau nonsurgical phase merupakan fase perawatan periodontal yang bertujuan untuk mengurangi poket periodontal, dan mengurangi atau menghilangkan gingival enlargement atau inflamasi gingiva. Perawatan yang dapat dilakukan pada nonsurgical phase antara lain edukasi kebersihan rongga mulut, scaling and Root Planing (SRP), mengkoreksi restorasi dan prostetik yang menjadi faktor iritasi, terapi antimikrobial, terapi oklusal, dan splinting. ${ }^{1}$

Surgical phase atau fase II merupakan fase dalam perawatan periodontal dengan melakukan pembedahan. Bedah peridontal bertujuan untuk mengurangi poket periodontal, memberi kemudahan akses bagi klinis untuk mencapai permukaan akar dan tulang alveolar serta memperbaiki jaringan periodontal. Perawatan yang dapat dilakukan pada surgical phase antara lain kuretase, gingivektomi, flap periodontal, dan regenerasi jaringan periodontal seperti cara soft tissue graft atau bone graft.

Restorative phase atau fase III dilakukan untuk mengembalikan fungsi pengunyahan, bentuk, dan estetika gigi. Pada fase perawatan ini dapat dilakukan final restoration atau jika dibutuhkan perawatan prostetik lepasan atau fixed.'

Maintenance phase atau fase IV merupakan fase perawatan periodontal yang sangat penting. Hal ini disebabkan karena pada fase ini dilakukan evaluasi terhadap perawatan yang sudah dilakukan sebelumnya. Pasien dievaluasi plak dan kalkulus, kondisi gingiva, oklusi dari gigi geligi, kegoyangan gigi dan perubahan patologi lainnya.'

Berdasarkan laporan kasus diatas, perawatan periodontal untuk pasien dengan periodontitis kronis disertai dengan penyakit diabetes melitus dilakukan setiap kunjungan sebagai berikut.

Kunjungan pertama perawatan yang dilakukan yaitu instruksi untuk menjaga kebersihan rongga mulut. Pasien diberikan edukasi dan motivasi untuk selalu menjaga kebersihan rongga mulut (Dental Health Education), rutin mengkonsumsi obat diabetes melitus, dan kontrol setelah 1 minggu. ${ }^{2}$ Scaling supragingiva merupakan tindakan untuk meng-hilangkan deposit lunak ataupun keras yang menempel pada gigi sehingga bakteri pada gigi tereliminasi. Medikasi yang pada kasus pasien diberikan obat kumur berupa povidone iodine agar tetap terjaga kebersihan rongga mulutnya.

Kunjungan kedua perawatan yang dilakukan yaitu maintenance. Pasien dilakukan evaluasi perawatan periodontal sebelumnya berupa evaluasi plak dan kalkulus, kondisi gingiva, derajat kegoyangan gigi, dan perubahan patologi lainnya.

Kunjungan ketiga perawatan yang dilakukan yaitu splinting. Splinting adalah suatu cara untuk mencegah terlepasnya gigi, mengontrol, dan menstabilkan kegoyangan gigi. Splint adalah alat yang digunakan untuk mendukung jaringan periodonsium yang lemah serta bertujuan untuk memberikan sandaran terhadap jaringan pendukung gigi selama proses penyembuhan setelah cedera atau proses pembedahan. Splint juga membantu gigi dalam melakukan fungsinya, ketika gigi dan jaringan pendukungnya tidak dapat berfungsi secara adekuat. ${ }^{10}$

Kunjungan keempat perawatan yang dilakukan yaitu maintenance. Pasien dilakukan evaluasi perawatan periodontal sebelumnya berupa evaluasi plak dan kalkulus, kondisi gingiva, derajat kegoyangan gigi, dan perubahan patologi lainnya.

Periodontitis kronis pada pasien dengan penyakit diaetes melitus yang tidak terkontrol akan meningkatkan resiko periodontitis dan resiko kehilangan gigi akan semakin besar. 
Bagi peneliti selanjutnya disarankan untuk melakukan perawatan yang lebih kompleks untuk kasus periodontitis pada pasien diabetes melitus.

\section{DAFTAR PUSTAKA}

1. Newman MG, Takei HH., Klokkevold PR. Carranza's Clinical Periodontology 13th Edition, Saunders Elsevier, Missouri, 2019.

2. Kinane DF, Stathopoulou PG., dan Papapanou PN, Periodontal Disease, Nature Review Diasese Primer. 2017; 3(17038): 1-14.

3. Hussain M, Ahsan S, Hassan SI., Yazdanie N, Khan MY, Khan M. Diabetes Melitus patients: Immediate Denture, Proffesional Medical Journal. 2015; 22(11): 1409-14.

4. Ermawati T., Periodontitis dan Diabetes Mellitus, Stomatognatic (J.K.G Unej). 2012; 9(3): 152-4.

5. Chaudhary $\mathrm{N}$ dan Tyaghi N. Diabetes Mellitus : An Overview, Chaudhary, N., dan Tyaghi, N., Diabetes Mellitus : An Overview, International Journal of
Research and Development in Pharmacy \& Life Science. 2018; 7(4): 3030-3.

6. Arifiana VD dan Prandita N. Penatalaksanaan Periodontitis Kronis pada Penderita Diabetes Mellitus, Stomatognatic (J.K.G Unej). 2019; 16(2): 59-63.

7. Andriani I, Chairunnisa FA, Periodontitis Kronis dan Penatalaksaan Kasus dengan Kuretase, Insisiva Dental Journal. 2019; 8(1): 25-30.

8. Surachman A, Paramita M., Kurniawan AA. Laporan Kasus: Manajemen Perawatan Gigi pada Pasien dengan Periodontitis Kronis disertai Diabetes Mellitus, Stomatognatic (J.K.G Unej). 2019; 16(1): 1-6.

9. Fishcer D, Treister S, Pinto A. Risk Assessment and Oral Diagonostics in Clinical Dentistry, Wiley, USA. 2013.

10. Bhuvaneswari P, Gowri T, Ram Kumar GD., dan Vanitha M. Periodontal splinting: A review before planning a splint, International Journal of Applied Dental Sciences. 2019; 5(4): 315-9. 